\title{
Investigation of Desulfurization Activity, Reusability, and Viability of Magnetite Coated Bacterial Cells
}

\author{
Hassan Bardania ${ }^{1}$, Jamshid Raheb ${ }^{2, *}$, Ayyoob Arpanaei ${ }^{3, *}$ \\ ${ }^{1}$ Cellular and Molecular Research Center, Yasuj University of Medical Sciences, Yasuj, Iran \\ ${ }^{2}$ Molecular Medicine, National Institute of Genetic Engineering and Biotechnology, Tehran, Iran \\ ${ }^{3}$ Industrial and Environmental Biotechnology, National Institute of Genetic Engineering and Biotechnology, Tehran, Iran \\ * Corresponding authors: Jamshid Raheb, Molecular Medicine, National Institute of Genetic Engineering and Biotechnology, Tehran, Iran; Tel: +98- \\ 2144787387; E-mail: jam@nigeb.ac.ir AND Ayyoob Arpanaei, Industrial and Environmental Biotechnology, National Institute of Genetic Engineering \\ and Biotechnology, Tehran, Iran; Tel: +98-21 44787463; E-mail: aa@nigeb.ac.ir
}

\begin{abstract}
Background: Magnetic separation using magnetic nanoparticles can be used as a simple method to isolate desulfurizing bacteria from a biphasic oil/water system.

Objectives: Magnetite nanoparticles were applied to coat the surface of Rhodococcus erythropolis IGTS8 and Rhodococcus erythropolis FMF desulfurizing bacterial cells, and the viability and reusability of magnetite-coated bacteria evaluated by using various methods.

Material and Methods: Magnetite nanoparticles were synthesized through a reverse co-precipitation method. Glycine was added during and after the synthesis of magnetite nanoparticles to modify their surface and to stabilize the dispersion of the nanoparticles. The glycine-modified magnetite nanoparticles were immobilized on the surface of both oil-desulfurizing bacterial strains. Reusability of magnetite-coated bacterial cells was evaluated via assessing the desulfurization activity of bacteria via spectrophotometry using Gibb's assay, after the separation of bacterial cells from 96h-cultures with the application of external magnetic field. In addition, CFU and fluorescence imaging were used to investigate the viability of magnetite-coated and free bacterial cells.

Results: TEM micrographs showed that magnetite nanoparticles have the size approximately $5.35 \pm 1.13 \mathrm{~nm}$. Reusability results showed that both magnetite-coated bacterial strains maintain their activity even after $5 \times 96 \mathrm{~h}$-cycles. The viability results revealed glycine-modified magnetite nanoparticles did not negatively affect the viability of two bacterial strains R. erythropolis IGTS8 and R. erythropolis FMF.

Conclusions: In conclusion, the glycine-modified magnetite nanoparticles have great capacity for immobilization and separation of desulfurizing bacteria from suspension.
\end{abstract}

Keywords: Rhodococcus erythropolis; Nanoparticles; Equipment Reuse

\section{Background}

Heavy crude oil with high caloric energy has a low commercial value because of impurities such as sulfur compounds and metals. In addition, the presence of sulfur compounds has been linked with the environmental problems. Therefore, the elimination of sulfur compounds from crude oil is indispensable due to global environment (1).

Sulfur dioxide and nitrogen dioxide can produce acid rain, which has known as a threat for the environment, the ecosystem, and public health (2). The current desulfurization method, i.e. hydro-desulfurization (HDS), is not an economical and efficient method for the elimination of sulfur compounds from crude oil. The disadvantages of HDS method lead the scientific community to focus on discovering new technologies $(2,3)$. Bio-desulfurization (BDS) process, as a safe method that removes sulfur from dibenzothiophene (DBT) derivatives specifically by biocatalysts under mild conditions, can potentially be employed as a complementary method with HDS. The other advantages of BDS method are the absence of detrimental by-products, low emission, and minimal energy cost. Therefore, this process is known as a promising method for removing sulfur from crude oil without reducing the caloric value of fossil fuel (4-6). DBT is utilized as a compound model in the basal salt 
mediums (BSM) used for bacterial cultivation. DBT is converted to 2-hydroxybiphely (2-HBP) during a biodesulfurization process $(7,8)$. The reaction progress is monitored by detecting DBT consumption and 2HBP production. Despite these advantages, there are several challenges facing the industrialization of the BDS approach. Among these challenges is the issue with the isolation of microbial biomass from a biphasic oil/water system. Compared to other approaches, magnetic separation is a simple, cost-effective, and moderate technique that has recently been studied (9-11).

In the recent decades, nanotechnology has been advanced increasingly and well-developed nanomaterials, such as magnetic nanoparticles, have found many applications in biomedicine (12-14). Magnetic nanoparticles are suitable for cell separation due to their unique magnetic properties $(15,16)$. Magnetite nanoparticles are synthesized by the simple method of chemical co-precipitation and their surfaces can easily be modified by various surfactants $(17,18)$. The surface-modified magnetite nanoparticles can be immobilized on the membrane of bacteria and magnetite-coated bacteria isolated from solution via applying an external magnetic-field (19-21).

In the previous studies, magnetite nanoparticles were immobilized on the surface of Pseudomans delafieldii, Rhodococcus erythropolis LSSE8-1, and Rhodococcus erythropolis IGTS8 bacterial cells, where the desulfurization activity and reusability of magnetite coated bacteria were evaluated $(19,20,22,23)$. On the other hand, in our prior study, we coated $R$. erythropolis IGTS8 and $R$. erythropolis FMF with glycine-modified magnetite nanoparticles and investigated the effect of magnetite nanoparticles on the desulfurization activity of bacterial strains (24). Our results demonstrated that the magnetite nanoparticles have not any influence on the desulfurization activity of the aforementioned bacterial strains.

\section{Objectives}

In this study, we evaluated the desulfurization activity and the reusability of magnetite-coated desulfurizing bacterial cells. In addition, the toxicity and the effect of iron oxide nanoparticles on the viability of bacteria cells were evaluated. Magnetite nanoparticles were characterized using transmission electron microscopy (TEM). Reusability of magnetite-coated desulfurizing bacteria was assessed during $5 \times 96$ h-cycles using Gibb's assay. Afterward, viability of magnetite coated bacteria was investigated via measuring colony forming unit (CFU) and fluorescent staining.

\section{Materials and Methods}

\subsection{Materials}

DBT and 2-HBP were obtained from Fisher (Germany), Gibb's reagent, 2, 6-dicholoroquinone-4chloromide, fluorescein diacetate, and propidium iodide from Sigma (USA). Ethyl acetate and all other chemicals were purchased from Merck (Germany).

\subsection{Bacterial Strains and Culture Medium}

The bacterial strains (Rhodococcus erythropolis IGTS8 and Rhodococcus erythropolis FMF from the Persian and American type culture collections, respectively) were cultured in basal salt medium (BSM). BSM is a sulfurfree medium which contains: $2.44 \mathrm{~g} \mathrm{KH}_{2} \mathrm{PO}_{4}, 5.57 \mathrm{~g}$ $\mathrm{Na}_{2} \mathrm{HPO}_{4}, 2.0 \mathrm{~g} \mathrm{NH}_{4} \mathrm{CL}, 0.2 \mathrm{~g} \mathrm{MgCl}_{2} .6 \mathrm{H}_{2} \mathrm{O}, 0.001 \mathrm{~g}$ $\mathrm{CaCl}_{2} .2 \mathrm{H}_{2} \mathrm{O}, \quad 0.001 \mathrm{~g} \quad \mathrm{FeCl}_{3} \cdot 6 \mathrm{H}_{2} \mathrm{O}, \quad 0.004 \mathrm{~g}$ $\mathrm{MnCl}_{2} .4 \mathrm{H}_{2} \mathrm{O}, 2 \mathrm{~mL}$ glycerol per liter. In addition, DBT $(0.54 \mathrm{mmol})$ as a sulfur source to the final concentration of $100 \mathrm{ppm}$.

\subsection{Synthesis of Magnetite Nanoparticles}

Iron oxide nanoparticles were synthesized by using reverse coprecipitation method $(25,26)$ with adding glycine during and after synthesis to stabilize the dispersion of nanoparticles. In this method, salt solution was prepared by adding ferric chloride hexa-hydrate $\left(\mathrm{FeCl}_{3} \cdot 6 \mathrm{H}_{2} \mathrm{O}\right)$ and ferrous chloride tetra-hydrate $\left(\mathrm{FeCl}_{2}\right.$ $4 \mathrm{H}_{2} \mathrm{O}$ ) with 2:1 molar ratio to $5 \mathrm{~mL}$ of deionized water and $0.17 \mathrm{~mL}$ of $\mathrm{HCl}(12 \mathrm{M})$. Then, the salt solution was slowly added to be previously prepared alkaline solution of Ammonia ( $\mathrm{pH} 9$ ) under a stream of $\mathrm{N}_{2}$. The ammonia solution was strongly stirred with mechanical agitator during of adding salt solution. Glycine was added as a surfactant in two steps during synthesis $(1.5 \mathrm{~mL} 0.27$ g.mL ${ }^{-1}$ ) and after synthesis (three $\mathrm{mL}$ glycine 0.4 g.mL $\left.{ }^{1}\right)$. After 30 minutes of agitation, the precipitate of synthesized nanoparticles was sonicated for 20 minutes. Finally, nanoparticles were washed by deionizeddeoxygenated water three times and were re-suspended in $40 \mathrm{~mL}$ of deionized-deoxygenated water.

\subsection{Magnetic Coating of Bacteria and Magnetic Cell Separation}

$50 \mathrm{~mL}$ of culture medium (Luria's broth (LB)), containing bacterial cells grown until the midexponential phase (about 0.3 g.. $\mathrm{L}^{-1}$ ), was harvested by centrifugation ( $4500 \mathrm{rpm}$ for 10 minutes) and the pellet of cells was washed by physiological water $(0.85 \% \mathrm{NaCl}$ in distilled water). Then, the pellets were re-suspended into $40 \mathrm{~mL}$ of BSM. $5 \mathrm{~mL}$ of magnetic fluids (10 g.L $\left.\mathrm{L}^{-1}\right)$ was added to the solution and was thoroughly mixed with it. After the magnetite-coated cells were isolated from the solution by using external magnetic field, they were cultured in BSM. Separation of magnetite-coated and free bacteria was performed during $5 \times 96$ h-cycles. After each cycle, their desulfurization activity was analyzed by Spectrophotometric Gibbs assay.

\subsection{Spectrophotometric Gibb's Assay}

Desulfurization activity was examined by the Gibb's reagent (2,6-dichloroquinone-4-chloroimide) to detect the aromatic components containing hydroxyl group such as 2 -HBP. The measuring of concentration of these compounds is performed by spectrophotometer (uv- 
visible JENWAY-Genova) at $610 \mathrm{~nm}$ after $30 \mathrm{~min}$ incubation in $30^{\circ} \mathrm{C}$ temperature $(27,28)$.

\subsection{Characterization of Magnetite Nanoparticles and Magnetite-Coated Bacterial Cells \\ The size and morphology of nanoparticles and immobilization of nanoparticles on the cell surface of bacteria were analyzed by transmission electron microscope (TEM) (Philips CM 200, $200 \mathrm{kV}$ TEM, ATM $2 k^{*} 2 \mathrm{k}$ CCD Camera).}

3.7. Colony-Forming Init (CFU) Assay for Evaluation of Viability of Free and Magnetite-Coated Bacteria

After the first and the second cycles, the CFU assay was performed to evaluate the viability of magnetic-coated bacteria in comparison with free bacteria. For that, 500 $\mu \mathrm{L}$ of the medium of $96 \mathrm{~h}$-cultured magnetite-coated and free bacterial cells were serially diluted with physiologic water, with 6-fold dilution in each step. Bacterial suspension was cultured on LB agar plates. The colonyforming units were counted and expressed as CFU.mL ${ }^{-1}$ following serial dilution.

\subsection{Viability Probes and Staining Protocol}

\subsubsection{Fluorescent Reagent}

Fluorescein diacetate (FDA) and propidium iodide (PI) working solutions were respectively prepared at $5 \mathrm{mg} . \mathrm{ml}$ in $100 \%$ acetone and $2 \mathrm{mg} . \mathrm{ml}$ in water and their aliquots were separately stored in single-usage tubes at $-20^{\circ} \mathrm{C}$.

\subsubsection{Staining Protocol}

Fluorescent staining was used to analyze bacteria viability. For that, one $\mathrm{mL}$ of the medium of $96 \mathrm{~h}$ cultured magnetite-coated and free bacterial cells were harvested. Bacterial cells were washed by PBS solution and centrifuged at $4000 \mathrm{rpm}$ for 5 minutes at $4^{\circ} \mathrm{C}$. The supernatant was removed and the pellet was resuspended in PBS solution. $50 \mu \mathrm{L}$ of PI and $10 \mu \mathrm{L}$ of FDA was added to the bacterial solution and mixed thoroughly. After 3-minute incubation in dark and at room temperature, vials were placed on ice. Finally, these samples were observed under fluorescent microscope (Zeiss Germany).

All of these experiments were performed for both $R$. erythropolis FMF and R. erythropolis IGTS8 bacterial cells.

\subsection{Statistical Analysis}

All analysis performed to evaluate the viability and the reusability of magnetite-coated and free bacterial cells was repeated three times and the results are reported as mean \pm standard deviation in the resulting plots. To determine the statistical significance, all experimental data were analyzed by t-test and univariate analysis using SPSS version 16.0.

\section{Results}

4.1. Characterization of Magnetite Nanoparticles and Immobilization of Magnetite Nanoparticles on the Surface of Bacteria

TEM analysis demonstrated that synthesized nanoparticles had size $5.35 \pm 1.13 \mathrm{~nm}$ (Fig. 1). The data from the immobilization of magnetite nanoparticles on the surface of bacterial cells were reported in our previous work (24). Positively charged magnetite nanoparticles were spontaneously absorbed on the surface of bacterial cells because of the negative charge of the surface of bacterial cells (Fig. 2).

A

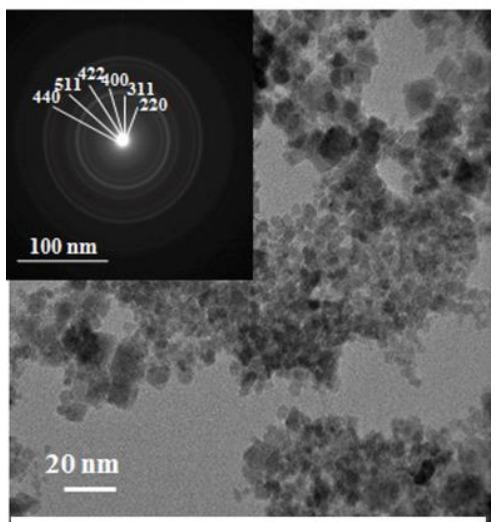

B

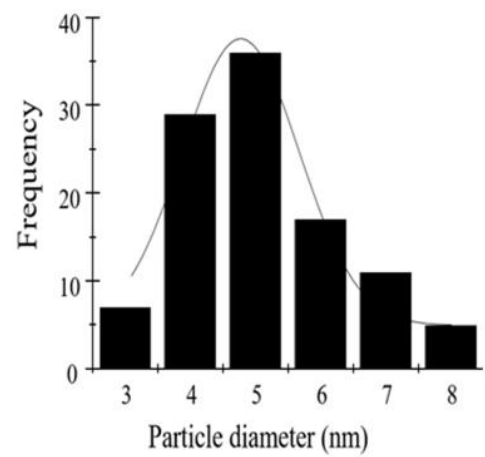

Figure 1. TEM Micrographs (A) and size distribution (B) of glycinemodified magnetite nanoparticles.

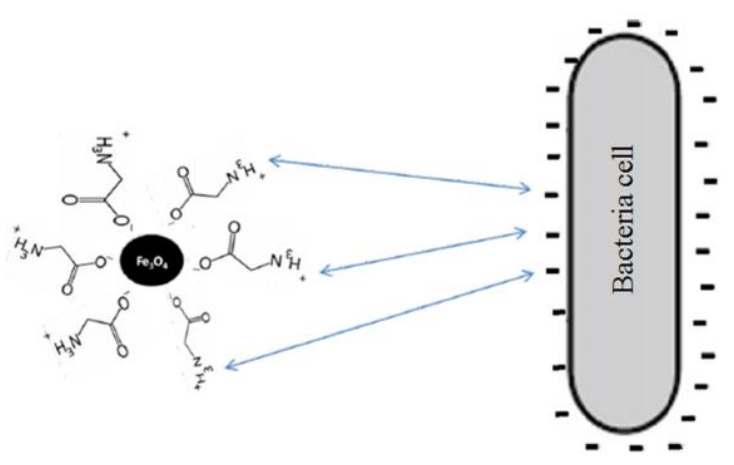

Figure 2. Schematic illustration of absorption of glycine-modified $\mathrm{Fe}_{3} \mathrm{O}_{4}$ nanoparticles on the surface of bacteria cells 


\subsection{Evaluation of Reusability of Magnetite-Coated} Bacteria

Reusability of magnetite-coated R. erythropolis IGTS 8 and $R$. erythropolis FMF bacterial cells were evaluated in comparison with free bacteria during $5 \times 96$ h-cycles. The results demonstrate that both magnetite-coated bacterial strains maintain their desulfurization activity even after five cycles (Fig. 3). In addition, the significance was assessed at $95 \%$ confidence level $(\mathrm{P}<0.05)$ using univaraite statistical analysis. Our results show that there is no different between the types of bacteria in two magnetite-coated and free states, but there are significance changes between time intervals. The first significant difference is between the primary cycle with other cycles in both free and magnetitecoated states. However, the second is between 5th of cycles of utilizing of magnetite-coated bacteria with 2, 3 and 4th cycles.
4.3. Viability Assays of Magnetite-Coated and Free Bacteria

CFU and fluorescent imaging were utilized for viability analysis of two R. erythropolis FMF and R. erythropolis IGTS8 bacteria in two magnetite-coated and free states. $\mathrm{CFU}$ is one of the most common methods for analyzing of cell viability. The results from this assay showed that the number of viable cells of magnetite-coated bacteriahas negligible decrease compared to free bacteria during different times of the first and second cycles (Fig. 4). Stained magnetite-coated and free bacterial cells with these fluorescent dyes were imaged by a fluorescent microscope. The results exhibited that the most of bacterial cells were alive (green colored) in both magnetite-coated and free states and the difference between the number of green-colored bacterial cells in two states was negligible (Fig. 5).

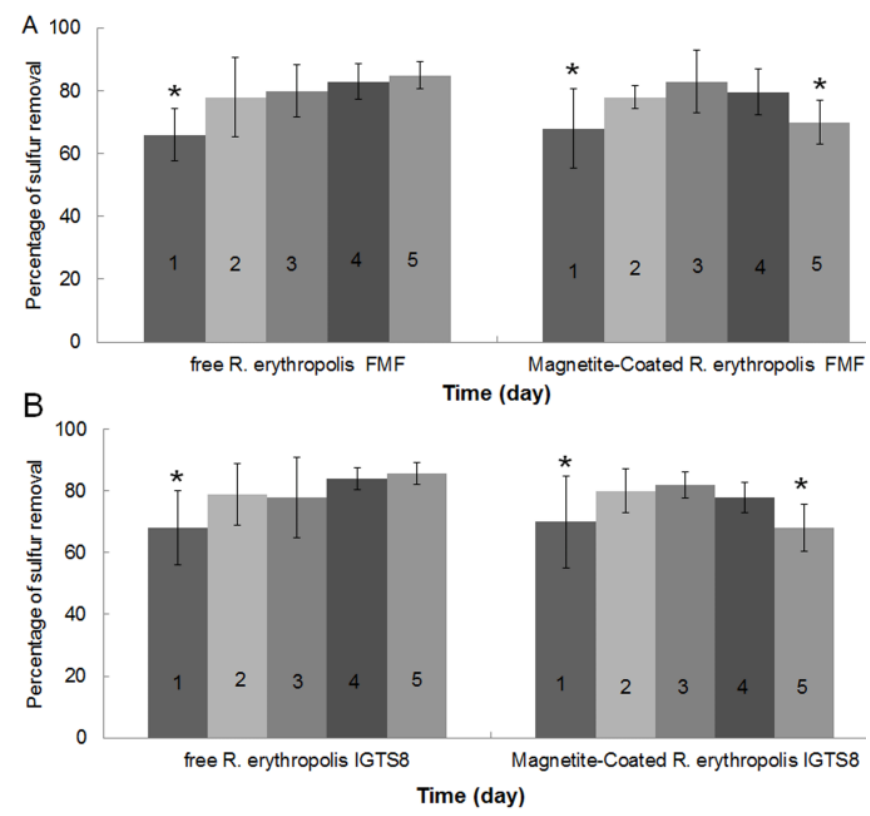

Figure 3. Repeated desulfurization activity of free and magnetite coated R. erythropolis FMF (A) and R. erythropolis IGTS8 (B). Data are expressed as mean \pm SD of three independent experiments. ${ }^{*}$ denotes a statistically significant $(\mathrm{P}<0.05)$ difference with other cycles.

\section{Discussion}

Glycine-modified magnetite nanoparticles were synthesized and immobilized on the surface of desulfurizing bacteria cells. Glycine, as a surfactant, can be immobilized on the surface of magnetite nanoparticles through carboxyl group $(\mathrm{COOH})$. The immobilization of glycine on the surface of nanoparticles prevents the aggregation of nanoparticles and, due to its amine groups $\left(\mathrm{NH}_{2}\right)$, imbue nanoparticles with positive charge $(29,30)$. In addition, positively-charged-glycine-modified magnetite nanoparticles can simultaneously immobilize on the negatively charged surface of bacteria. The surface charge of both gram negative and gram positive bacteria is negative, but amount of surface charge can be reduced or increased proportional to the frequency of anionic groups on their surfaces (31).

Reusability of magnetite coated and free desulfurizing bacteria were evaluated for $5 \times 96 \mathrm{~h}$ cycles. In the initial cycle, the bacterial cells, which were previously cultured in $\mathrm{LB}$, were transferred from a rich medium (i. e. $\mathrm{LB}$ ) to the basal salt medium (BSM). Consequently, the significance different between first cycle with other cycles may be due to the low compatibility of bacteria with minimal medium. On the other hand, the desulfurization activity of magnetite-coated bacteria in fifth cycle has significance decrease with the second, third and fourth cycles, which is in accordance with the results of Guobin et al. 

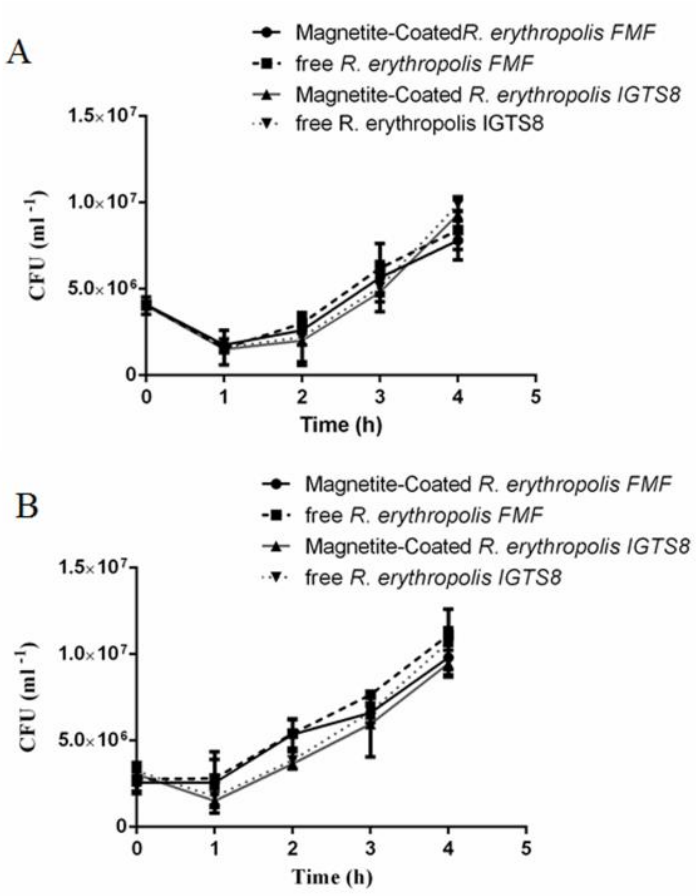

Figure 4. Viability of free and magnetite coated bacteria cells in first (A) and second (B) usage. The CFU data are expressed as mean \pm SD of three independent experiments
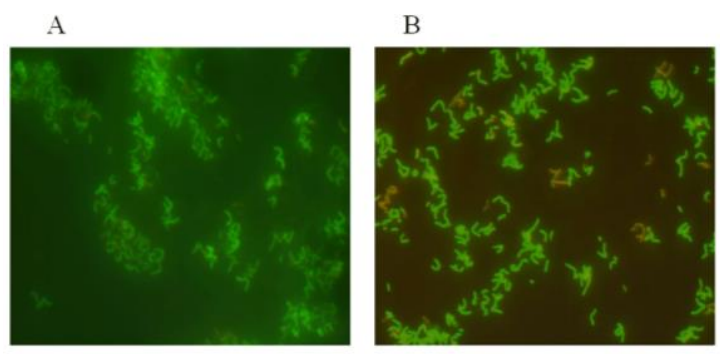

C

D
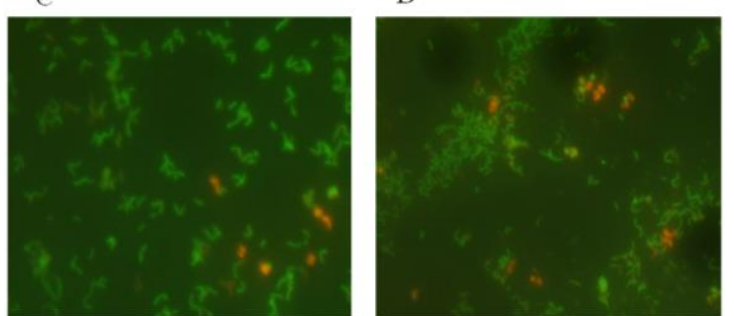

Figure 5. Fluorescent images of free (A) and magnetite coated (B) R. erythropolis FMF and free (C) and magnetite coated (D) $R$. erythropolis IGTS8 in first usage.

They evaluated the reusability of magnetite-coated Pseudomonas delafieldii bacterium for five cycles and reported that the magnetite-coated bacteria need more time to desulfurize the oil in the later cycles, and that the desulfurization activity of magnetite-coated bacteria decreased over time (22). The growth and proliferation - as well as enzymatic activity- of cultured bacteria in the minimal mediums of BSM could diminish over time, which could explain the reduction observed by Guobin et al. Moreover, it can be because of decrease in magnetite-coated cell numbers during five cycles. In addition, Li et al considered the reusability of magnetite- coated R. erythropolis LSSE8, and their results demonstrated that magnetite-coated bacteria maintain their desulfurization activity after some 20h-cycles; In addition, they showed that magnetite nanoparticles have high efficiency to separation of magnetite-coated bacteria (20).

Fluorescent staining by FDA and PI dyes was used to evaluate bacterial viability. FDA can easily penetrate to living cells through plasma membrane and be hydrolyzed and converted to fluorescein with color green fluorescent in the presence of diesterase enzymes. Therefore, alive cells are colored green with the accumulation of the fluorescein dye (32). On the other hand, PI cannot pass plasma membrane and enter into living cells. It can only enter to a dead or membranedamaged cells and bond to DNA. Therefore, dead bacterial cells are colored red with using of this fluorescent dye $(32,33)$.

The results show that more magnetite coated bacteria are alive in line with other studies which showed magnetic nanoparticles have no toxic effect on bacterial or eukaryote cells $(32,34,35)$. Some studies have evaluated the toxicity of magnetite nanoparticles on eukaryote cells $(34,35)$ and reported that the magnetite nanoparticles, having been functionalized with different surfactants, have no toxic effect on eukaryote cells. In addition, very few studies investigated the effect of magnetite nanoparticles on the viability of bacteria (32). They showed that $\mathrm{Fe}_{3} \mathrm{O}_{4}$ nanoparticles at 0.3 , 0.6, and $1.0 \mathrm{~g}$ Fe.L have no inhibitory and adverse effect on the growth and the survival of bacterial cells. In addition, they demonstrated that stabilized magnetite nanoparticles interact with bacterial surfaces without causing sufficient damage to inhibit cell growth and viability (32).

\section{Conclusions}

The synthesis of magnetite nanoparticles with cheap precursor materials is easy and has the potential to using in industrial application. The results showed that the magnetite-coated bacteria can maintain desulfurization activity even after $5 \times 96$ h-cycles. Glycine-modified magnetite nanoparticles have no toxic effect on the viability and the desulfurization activity of bacteria. In conclusion, glycine-functionalized magnetite nanoparticles can be used to separate microbial biomass from water/oil biphasic system.

\section{Conflict of Interest}

All authors declare that there is no conflict of interest.

\section{Acknowledgement}

This work was financially supported by the National Institute of Genetic Engineering and Biotechnology of Iran. The authors thank Prof. Hojatollah Vali (Facility for Electron Microscopy Research, McGill University, Montreal, Canada) for expert technical assistance with TEM analysis. 


\section{References}

1. Francisco M, Arce A, Soto A. Ionic liquids on desulfurization of fuel oils. Fluid Phase Equilibr. 2010;294:39-48.

2. Soleimani M, Bassi A, Margaritis A. Biodesulfurization of refractory organic sulfur compounds in fossil fuels. Biotechnol Adv. 2007;25(6):570-596. doi: 10.1016/j.biotechadv.2007.07.003 pmid: 17716849

3. Gupta N, Roychoudhury PK, Deb JK. Biotechnology of desulfurization of diesel: prospects and challenges. Appl Microbiol Biotechnol. 2005;66(4):356-366. doi: 10.1007/s00253-004-1755-7 pmid: 15538557

4. Mohebali G, Ball AS. Biocatalytic desulfurization (BDS) of petrodiesel fuels. Microbiology. 2008;154(Pt 8):2169-2183. doi: 10.1099/mic.0.2008/017608-0 pmid: 18667551

5. Boniek D, Figueiredo D, dos Santos AFB, de Resende Stoianoff MA. Biodesulfurization: a mini review about the immediate search for the future technology. Clean Technol Environ Pol. 2015;17(1):29-37.

6. Abro R, Abdeltawab AA, Al-Deyab SS, Yu G, Qazi AB, Gao $S$, et al. A review of extractive desulfurization of fuel oils using ionic liquids. RSC Adv. 2014;4(67):3530235317.

7. Calzada J, Zamarro MT, Alcon A, Santos VE, Diaz E, Garcia JL, et al. Analysis of dibenzothiophene desulfurization in a recombinant Pseudomonas putida strain. Appl Environ Microbiol. 2009;75(3):875-877. doi: 10.1128/AEM.01682-08 pmid: 19047400

8. Gunam IBW, Iqbal M, Arnata IW, Antara NS, Anggreni D, Made AA, et al., editors. Biodesulfurization of dibenzothiophene by a newly isolated Agrobacterium tumefaciens LSU20. Applied Mechanics and Materials; 2017: Trans Tech Publ.

9. Gupta AK, Naregalkar RR, Vaidya VD, Gupta M. Recent advances on surface engineering of magnetic iron oxide nanoparticles and their biomedical applications. Nanomedicine (Lond). 2007;2(1):23-39. doi: 10.2217/17435889.2.1.23 pmid: 17716188

10. Haukanes BI, Kvam C. Application of magnetic beads in bioassays. Biotechnology (N Y). 1993;11(1):60-63. pmid: 7763485

11. Majewski AP, Schallon A, Jerome V, Freitag R, Muller $\mathrm{AH}, \mathrm{Schmalz} \mathrm{H}$. Dual-responsive magnetic core-shell nanoparticles for nonviral gene delivery and cell separation. Biomacromolecules. 2012;13(3):857-866. doi: 10.1021/bm2017756 pmid: 22296556

12. Achilefu S, Raghavachari R, editors. Reporters, Markers, Dyes, Nanoparticles, and Molecular Probes for Biomedical Applications X. Proc of SPIE Vol; 2018.

13. Simonsen G, Strand M, Øye G. Potential applications of magnetic nanoparticles within separation in the petroleum industry. J Petrol Sci Eng. 2018(165):488495.

14. Malekzadeh M, Nejaei A, Baneshi MM, Kokhdan EP, Bardania $\mathrm{H}$. The use of starch-modified magnetic $\mathrm{Fe} 0$ nanoparticles for naphthalene adsorption from water samples: Adsorption isotherm, kinetic and thermodynamic studies. Appl Organometal Chem. 2018;32(8):e4434.

15. Kouassi GK, Irudayaraj J, McCarty G. Examination of Cholesterol oxidase attachment to magnetic nanoparticles. J Nanobiotechnology. 2005;3(1):1. doi: 10.1186/1477-3155-3-1 pmid: 15661076
16. Molday RS, Yen SP, Rembaum A. Application of magnetic microspheres in labelling and separation of cells. Nature. 1977;268(5619):437-438. pmid: 302417

17. Gupta AK, Gupta M. Synthesis and surface engineering of iron oxide nanoparticles for biomedical applications. Biomaterials. 2005;26(18):3995-4021. doi: 10.1016/j.biomaterials.2004.10.012 pmid: 15626447

18. Berry CC, Curtis AS. Functionalisation of magnetic nanoparticles for applications in biomedicine. J Phys D Appl Phys. 2003;36(13):R198.

19. Ansari F, Grigoriev P, Libor S, Tothill IE, Ramsden JJ. DBT degradation enhancement by decorating Rhodococcus erythropolis IGST8 with magnetic $\mathrm{Fe} 3 \mathrm{O} 4$ nanoparticles. Biotechnol Bioeng. 2009;102(5):1505-1512. doi: 10.1002/bit.22161 pmid: 19012265

20. Li YG, Gao HS, Li WL, Xing JM, Liu HZ. In situ magnetic separation and immobilization of dibenzothiophene-desulfurizing bacteria. Bioresour Technol. 2009;100(21):5092-5096. doi: 10.1016/j.biortech.2009.05.064 pmid: 19541480

21. Zakaria B, Nassar H, Saed D, El-Gendy NS. Enhancement of Carbazole Denitrogenation Rate Using Magnetically Decorated Bacillus clausii BS1. Petrol Sci Technol. 2015;33(7):802-811.

22. Shan G, Xing J, Zhang H, Liu H. Biodesulfurization of dibenzothiophene by microbial cells coated with magnetite nanoparticles. Appl Environ Microbiol. 2005;71(8):4497-4502. doi: 10.1128/AEM.71.8.44974502.2005 pmid: 16085841

23. Etemadifar Z, Derikvand P, Emtiazi G, Habibi MH. Response Surface Methodology Optimization of Dibenzothiophene Biodesulfurization in Model Oil by Nanomagnet Immobilized Rhodococcus Erythropolis R1. J Mater Sci Eng. 2014;4(10):322-330.

24. Bardania H, Raheb J, Mohammad-Beigi H, Rasekh B, Arpanaei A. Desulfurization activity and reusability of magnetite nanoparticle-coated Rhodococcus erythropolis FMF and R. erythropolis IGTS8 bacterial cells. Biotechnol Appl Biochem. 2013;60(3):323-329. doi: 10.1002/bab.1090 pmid: 23656694

25. Mohammad-Beigi H, Yaghmaei S, Roostaazad R, Bardania $\mathrm{H}$, Arpanaei A. Effect of $\mathrm{pH}$, citrate treatment and silane-coupling agent concentration on the magnetic, structural and surface properties of functionalized silica-coated iron oxide nanocomposite particles. Phys Low Dimens Syst Nanostruct. 2011;44(3):618-627.

26. Massart R. Preparation of aqueous magnetic liquids in alkaline and acidic media. IEEE Transact Magnet. 1981;17(2):1247-1248.

27. Kayser KJ, Bielaga-Jones BA, Jachowski K, Odusan O, Kilbane JJ. Utilization of organosulfur compounds by axenic and mixed culture of Rhodococcus rhodochrous IGTS8. J Gen Microbiol. 1993;139:3123 - 3129.

28. Monticello DJ. Continuous process for biological desulfurization of sulfur-bearing heterocyclic molecules. United States Patent 5472 875. USA: Energy Biosystems Corp; 1995.

29. Hu C, Gao Z, Yang X. Fabrication and magnetic properties of Fe 3 O 4 octahedra. Chem Phys Lett. 2006;429(4):513-517.

30. Viota JL, Arroyo FJ, Delgado AV, Horno J. Electrokinetic characterization of magnetite 
nanoparticles functionalized with amino acids. J Colloid Interface Sci. 2010;344(1):144-149. doi: 10.1016/j.jcis.2009.11.061 pmid: 20096847

31. Katas H, Mohamad A, Zin NM. Physicochemical effects of chitosan-tripolyphosphate nanoparticles on antibacterial activity against Gram-positive and Gramnegative bacteria. J Med Sci. 2011;11(4):192-197.

32. Freeland Starr K. Microbial Implication of Iron Oxide Nanoparticles. USA: Auburn University; 2010.

33. Negahdary M, Omidi S, Eghbali-Zarch A, Mousavi SA, Mohseni G. Plant synthesis of silver nanoparticles using Matricaria chamomilla plant and evaluation of its antibacterial and antifungal effects. Biomed Res. 2015;26:794-799.

34. Mahmoudi M, Simchi A, Milani AS, Stroeve P. Cell toxicity of superparamagnetic iron oxide nanoparticles. J Colloid Interface Sci. 2009;336(2):510-518. doi: 10.1016/j.jcis.2009.04.046 pmid: 19476952

35. Hafeli UO, Riffle JS, Harris-Shekhawat L, CarmichaelBaranauskas A, Mark F, Dailey JP, et al. Cell uptake and in vitro toxicity of magnetic nanoparticles suitable for drug delivery. Mol Pharm. 2009;6(5):1417-1428. doi: 10.1021/mp900083m pmid: 19445482 